Uludag Univ. J. Fac. Vet. Med.

34 (2015), 1,2: 9-13

\title{
Ratlarda Barsak Mikroflorası Gelişimi Üzerine Diyet Kısıtlaması ile Beslenmenin Etkisi
}

\author{
Tülay ELAL MUŞ ${ }^{1} \quad$ Füsun AK SONAT ${ }^{2}$
}

Geliş Tarihi: 18-06-2015

Kabul Tarihi: 27-08-2015

\begin{abstract}
Özet: Bu çalışma ratlara uygulanan uzun süreli diyet kısıtlamasının barsak mikroflorası üyesi olan laktobasil, koliform bakteri, enterokok ve Enterobactericeae sayıları üzerine etkisini ortaya koymak amacıyla gerçekleştirildi. Bu amaçla ratlar iki gruba ayrıldı. Birinci gruba 150 gün süresince diyet kısıtlaması uygulanırken ikinci grup ratlar kontrol grubuydu ve ad libitum olarak beslendi. Her iki grup rata ait feçes örnekleri 1., 30., 60., 90., 120. ve 150. günlerde toplanarak mikrobiyolojik analizleri gerçekleştirildi. Analiz sonuçlarına göre; diyet kısıtlaması uygulanan ratların feçesindeki laktobasil, koliform bakteri ve Enterobactericeae sayıları 150. günün sonunda yaklaşık $1 \log$ artış gösterirken, enterokok sayısı aynı düzeyde belirlendi. Diyet kısıtlaması grubunda sadece probiyotik özelliğe sahip bir bakteri olan laktobasil sayısında istatistiksel anlamlılık $(\mathrm{p}=0.02)$ ortaya çıktı. Kontrol grubunda ise yalnız enterokok sayısında $2 \log 10$ düşme gözlenirken diğer bakteri gruplarının sayılarında değişiklik gözlenmedi. Gruplar arasında yapılan istatistiksel karşılaştırmada koliform bakteri ve Enterobactericeae sayılarınla anlamlı farklılık $(\mathrm{p}<0.05)$ bulunurken laktobasil ve enterokok sayılarında anlamlılık belirlenmedi $(\mathrm{p}>0.05)$. Sonuç olarak, uzun süreli diyet kısıtlamasının rat örneğinde barsak mikroflorasını değiştirme potansiyeline sahip olduğu belirlendi.
\end{abstract}

Anahtar Kelimeler: Diyet kısıtlaması, rat, feçes, mikroflora.

\section{Effect of Fed by Dietary Restriction on Evolution (Growth) of Intestinal Microflora in Rat}

\begin{abstract}
This study was conducted to evaluate the effect of the long-term dietary restriction applied to rat on counts of lactobacilli, coliform bacteria, enterococci and Enterobactericeae which are intestinal microflora members. For this purpose, rats vere divided to two groups. While the first group of rats were administrated dietary restrictions during 150 days, second group rats were control group and were fed by ad libitum. For both group, faeces samples of rats were collected at 1st, 30th, 60th, 90th, 120th and 150th days and microbiological analysis were performed. According to analysis results, lactobacillus, coliform bacteria enterococci and Enterobactericeae counts in the faeces of rats who was applied dietary restriction showed the a $1 \log 10$ increase in the end of the 150th day while enterococci counts were determined in the same level. A statistically significant difference $(p=0.02)$ was only observed in the counts of lactobacillus having probiotic properties in dietary restricted group. While a $2 \log 10$ decrease in only enterococci counts in control group was observed, any change in counts of other bacterial groups was not detected. Statistical comparison between groups showed that coliform bacteria and Enterobactericeae counts were statistically different $(p<0.05)$, while lactobacillus and enterococci counts were not statistically significant $(\mathrm{p}>0.05)$. As a result of this study, it was determined that the long-term dietary restriction in rat model has potential to change intestinal microflora.
\end{abstract}

Key Words: Dietary restriction, rat, faeces, microflora.

1 Uludağ Üniversitesi, Keles Meslek Yüksek Okulu, Gıda Teknolojisi Programı, Keles, Bursa.

2 Uludağ Üniversitesi, Veteriner Fakültesi, Fizyoloji Anabilim Dalı, Görükle, Bursa, fusunak@uludag.edu.tr 


\section{Giriş}

Sağlıklı kişilerin barsaklarında yaklaşık 500 farklı türde bakteri bulunur. Bu bakterilerin sayıs1 $10^{4}$ kob/g'a kadar çıkabilir (Coşkun 2006). Diyet, yaşam biçiminin düzenlenmesi, antibiyotik, probiyotik, prebiyotik ve sinbiyotiklerin kullanımı barsak mikroflorasının düzenlenmesinde rol oynayan faktörlerdir (Koca 2015). İnsanların yanı sira kanatlı hayvanlarda da rasyon değişikliği ile sindirim sistemi mikroflorasının değiştirilebildiği kabul edilmektedir (Tüzün 2010).

Diyet kisitlaması (DK) beslenme yetersizliğine (malnütrisyon) sebep olmaksızın normalden daha az beslenmek, diğer bir ifadeyle günlük kalori alımını kısıtlamak olarak tanımlanmaktadır (Robertson 2013, Aydın 2007). DK'nın maya (Saccharomyces cerevisiae), sinekler (Drosophila melanogaster), solucanlar (Caenorhabditis elegans) ve laboratuar kemirgenleri (rodent) gibi çok çeşitli canlılarda yaşlanmay1 geciktirici ve yaşam süresini uzatıcı etki meydana getirdiği ortaya konmuştur (Giller 2013, Aydin 2009). Bu olumlu etkiler arasinda diyette kısıtlamanın yaşam süresini uzatıcı (maksimum etki kaloride \% 55-60 kısitlama sonucu) etkisi üzerinde en fazla çalışılan konulardan biridir. Uzun süreli diyet kısitlamasının kanser hücrelerinin gelişimini yavaşlatıcı ve kanserin başlamasını geciktirici; insülin direnci ve metabolik sendromu \% 30'a kadar iyileştirici etkisi olduğu bildirilmiștir. DK'nın hastalıklar, yaşlanma ve yaşam süresini uzatmadaki bu olumlu etkileri meydana getiriyor olmadaki temel mekanizmanın, vücutta oluşan reaktif oksijen türlerinin miktarını azaltmasına bağlı olarak oksidatif stresi baskılamasından kaynaklandığı bildirilmektedir (Shimokawa, 2010). Yine diyet kisitlaması uygulanan hayvanlarda açlık hissine bağlı olarak fiziksel aktivitenin ve çiftleşme isteğinin arttığı, fakat dişi hayvanlarda fertilitenin azaldığı da belirlenmiştir. Uzun süreli diyet kisitlamasinin serum total kolesterol, LDL kolesterol ve trigliserid seviyesini düşürmekle birlikte sistolik ve diyastolik kan basınc1n1 azalttığ 1 tespit edilmiştir. Hücre içerisinde oksidatif stresi azaltıcı, beyin, kalp, karaciğer gibi çeşitli organlarda \% 30'a varan mitokondrial biyogenez oluşturma gibi metabolik etkiler gözlenmiştir (Speakman 2011). Olumlu etkilerinin yanı sıra DK'nın ratlarda öğrenme ve hatırlama kabiliyetini düşürdüğü (Rajab 2014), bilişsel fonksiyonları olumsuz etkilediği (Yanai 2004) bildirilmiştir. Diyet kısıtlamasının mey- dana getirdiği tüm bu etkileri oluşturan moleküler mekanizmalar halen açıklığa kavuşturulmuş değildir (Giller 2013).

DK her gün ya da haftada üç gün alınan gıda miktarını kısıtlayarak yapılabildiği gibi gün aşırı besleme (1 gün besleme, 1 gün yem vermeme) yoluyla da gerçekleştirilebilir. Diyet kisitlaması kalori kisitlaması olarakta adlandır1lır ve kısa süreli (3gün ile birkaç ay arası) ve uzun süreli (en az 6 ay, 1 yıl veya daha uzun) olarak ikiye ayrilır (Robertson 2013).

Mevcut çalışmanın amacı diyet kısıtlamas1 uygulanan sağliklı ratlarda gastrointestinal sistem mikroorganizmaları sayılarında ortaya çıkabilecek muhtemel değişiklikleri ortaya koymaktır. $\mathrm{Bu}$ amaçla koliform, enterokok, Enterobactericeae gibi barsaklarda rutin olarak bulunan bakteriler yanı sıra probiyotik özellikteki laktobasil sayıları belirlendi. Mevcut araştırma aynı zamanda diyet kısıtlamasının barsak mikroflorası üzerine etkilerini belirlemek için alanında gerçekleştirilen ilk çalışma olma özelliğini taşımaktadır.

\section{Materyal ve Metot}

Mevcut çalışmada U.Ü. Tıp Fakültesi, Deney Hayvanları Yetiştirme, Uygulama ve Araştırma Merkezi'nden sağlanan 20 adet 3 aylık Sprague-Dawley irk1 erkek rat kullanıldı. Tüm ratlar kontrollü olarak \%50-60 rutubet, 20$23^{\circ} \mathrm{C}$ sicaklığa ve 12 saat aydınlık (06:00, 18:00), 12 saat karanlık olarak ayarlanmış odada her bir kafeste 2-3 hayvan olacak şekilde tutuldu. Ratlara su ad libitum olarak verilirken, beslenmelerinde \% 18 protein $(\mathrm{min}), \% 2.5$ yağ (min), \% 4 lif (max), \% 5.5 kül (max), \% 57.0 azotsuz madde (max), metabolik enerji 2650 $\mathrm{kcal} / \mathrm{kg}(\min )$, \% 13 su (max) ve amino asit, vitamin, mineral içeriğine sahip pelet yem kullanıldı (İçerik bilgileri üretici firmadan alınmıştır). Ratlar her biri 10 hayvandan oluşacak şekilde 2 gruba ayrild, birinci gruba diyet kısitlaması uygulanırken ve ikinci grup kontrol grubu hayvanlarından oluştu. Kontrol grubuna ad libitum yem verilirken; diyet kısitlaması uygulanan ratlara protein, yağ, mineral madde eksikliği çekmeyecek şekilde sadece Pazartesi, Çarşamba ve Cuma günleri aç bırakıldı. Haftanın diğer günleri ad libitum yem verildi. Her iki grupta suyu ad libitum olarak tüketti (Elal Muş ve Ak Sonat 2015).

Her iki grup rattan 0., 30., 60., 90., 120., 150 'nci günlerde dışkı numunesi alındı. Aseptik 
koșullarda elde edilen her bir örnek $+4^{\circ} \mathrm{C}$ 'de muhafaza edildi ve en kısa sürede laboratuara getirilerek analizleri gerçekleştirildi.

Dışkı örneklerinden bakterilerin izolasyonu için, her bir numuneden $5 \mathrm{~g}$ alınarak 45 $\mathrm{ml}$, \% 0.1'lik peptonlu su içerisinde 2 dakika süreyle stomacherde (Seward stomacher, model 400 circulator) homojenize edildi. Hazırlanan homojenat kullanılmak suretiyle örneklerin seri dilüsyonları hazırlandı ve uygun dilüsyonlardan agar plaklarına ekimleri gerçekleştirildi. Laktobasillerin izolasyonunda De Man Rogosa and Sharpe (MRS) Agar plaklarına dökme plak tekniği ile ekimler gerçekleştirildi. Plaklar $37^{\circ} \mathrm{C}$ ' de 72 saat süreyle anaerobik koșullarda inkübe edildi. 72 saat sonunda agarda gelişim gösteren sar1-krem renkli koloniler Lactobacillus olarak tanımlandı (Jackson 2002). Örneklerde enterokok sayisını belirlemede Slanetz and Bartley Agar plaklarına yayma plak tekniğiyle ekimler yapıldı. Plaklar $35^{\circ} \mathrm{C}$ 'de 48 saat süreyle inkübasyona bırakıldı ve bu süre sonunda Slanetz and Bartley Agar'da üreyen pembe veya koyu kırmızı renkli koloniler enterokok olarak değerlendirildi. Violet Red Bile Agar dışkı örneklerinde koliform bakterilerin belirlenmesinde kullanıldı. Ekimler dökme plak tekniği ile gerçekleștirildi ve $37^{\circ} \mathrm{C}$ 'de $24-48$ saat süreyle fakültatif anaerobik koşullarda inkübe edildi. Agar plaklarında gelişen pembe koloniler koliform olarak kabul edildi ve sayımları yapıldı. Enterobactericeae grubu bakterilerin tespitinde Violet Red Bile Glucose Agar'a dökme plak tekniği ile numuneler ekildi. $37^{\circ} \mathrm{C}$ 'de $24-48$ saat süreyle bekletildi ve pembe-kırmızı koloniler Enterobactericeae olarak tanımlanarak sayımlar1 gerçekleştirildi (Roberts 2003).

İstatistiksel analizler BM SPSS Statistics 22 programı kullanılarak Kruskal Wallis testi ile gerçekleştirildi. Farklılık ortaya çıkan gruplarda, iki grubun karşılaş̧ırılmasında ve aynı zaman grubunun, diyet kisitlamasi-kontrol arasindaki farklılığın belirlenmesinde ise Mann-Whitney U testi yapıldı. Gruplar arasında farklılık, $\mathrm{p}<0.05$ anlamlılık düzeyine göre belirlendi.

$\mathrm{Bu}$ çalışma Uludağ Üniversitesi Hayvan Deneyleri Yerel Etik Kurulundan 2012-14/05 sayılı izin yazısı alındıktan sonra yapılmıştır.

\section{Bulgular}

Gerçekleştirilen çalışmada diyet kısıtlaması uygulanan ratların dışkısında laktobasil sayıs1 ortalamas1 1-150. günler arasında $1 \log _{10}$ artarken kontrol grubunda aynı seviyede kaldı. Diyet kısıtlaması grubunda gözlenen artış istatiksel olarak anlamlı $(\mathrm{p}=0.02)$ bulunurken kontrol grubunda istatistiksel bir anlam $(\mathrm{p}=0.32)$ yoktu. İki grubun laktobasil sayılarına ait veriler arasında karşılaştırma yapıldığında bir anlamlılik $(\mathrm{p}=0.222)$ bulunmadi. Ayrica diyet kisitlamas1 uygulanan grupta 1-60. $(\mathrm{p}=0.01), 1-120$. $(p=0.01)$ ve 30-120. $(p=0.03)$ günler arası laktobasil sayılarında anlamlıl1k belirlendi. Kontrol grubunda ise 1-90. ( $\mathrm{p}=0.03), 30-90 . \quad(\mathrm{p}=0.01)$, 60-90. $(\mathrm{p}=0.01)$ ve 90-120. $(\mathrm{p}=0.03)$ günler arasında farklılık tespit edildi. 1. -150. günlere göre laktobasil sayılarına ait veriler tablo 1'de özetlendi.

Tablo 1: 1.-150. günlere göre laktobasil sayı$\operatorname{larl}\left(\log _{10} \mathrm{kob} / \mathrm{g}\right)$

Table 1: Lactobacillus spp. counts $\left(\log _{10}\right.$ $\mathrm{kob} / \mathrm{g}$ ) according to days 1.-150.

\begin{tabular}{|ccccccc|}
\hline \multicolumn{6}{c|}{ Laktobasil sayıları } \\
\cline { 2 - 7 } Günler & \multicolumn{3}{c|}{ Diyet Kısıtlaması } & \multicolumn{4}{c|}{ Kontrol } \\
\cline { 2 - 8 } & Min. $\begin{array}{c}\text { Ortalama } \\
\pm \text { SEM }\end{array}$ & Mak. & Min. & $\begin{array}{c}\text { Ortalama } \\
\pm S E M\end{array}$ & Maks. \\
\hline 1. & 7.49 & $7.88 \pm 0.16$ & 8.41 & 8.04 & $8.45 \pm 0.14$ & 8.90 \\
30. & 8.23 & $8.38 \pm 0.08$ & 8.67 & 8.11 & $8.43 \pm 0.11$ & 8.77 \\
60. & 8.14 & $8.66 \pm 0.16$ & 9.10 & 8.55 & $8.60 \pm 0.02$ & 8.68 \\
90. & 7.69 & $8.47 \pm 0.21$ & 8.95 & 8.61 & $8.92 \pm 0.09$ & 9.14 \\
120. & 8.36 & $8.80 \pm 0.12$ & 9.03 & 8.56 & $8.65 \pm 0.04$ & 8.77 \\
150. & 7.69 & $8.84 \pm 0.30$ & 9.34 & 8.50 & $8.62 \pm 0.04$ & 8.64 \\
\hline
\end{tabular}

Koliform bakteri sayıs1 diyet kisitlamas1 grubunda yaklaşı $1 \log _{10}$ 'luk artış gösterirken, kontrol grubunda bir değişiklik tespit edilmedi. Gruplar arası karşılaştırmada koliform bakteri sayısında anlamlılık $(\mathrm{p}=0.01)$ gözlendi. Benzer şekilde Enterobactericeae sayıs1 diyet kisitlamas1 grubunda artarken, kontrol grubunda değişmedi ve diyet kısitlaması ve kontrol grupları arasında istatistiksel olarak anlamlılık $(\mathrm{p}=0.00)$ bulundu. Enterokok sayısında 30. günde anlaml1lı ( $\mathrm{p}=0.00)$ belirlenirken, diğer bakteri gruplarının aksine 150 günlük diyet kısıtlaması sonrası enterokok sayısı değişiklik göstermedi. Enterokok sayıs1 kontrol grubunda $1 \log _{10}$ düştü ve grup içinde anlamlı bir farklılık $(\mathrm{p}=0.00)$ tespit edildi. İki grup arasında enterokok sayıları karşılaştırıldığında anlamlılık $(\mathrm{p}=0.15)$ ortaya çıkmadi. Gruplara ve günlere göre koliform bakteri, enterokok ve Enterobactericeae sayıları tablo 2'de özetlendi. 
Tablo 2: Gruplara ve 1.-150. günlere göre koliform bakteri, enterokok ve Enterobactericeae sayıları $\left(\log _{10}\right.$ kob/g)

Table 2: Coliform bacteria, Enterococci and Enterobactericeae counts $\left(\log _{10}\right.$ kob/g) according to days 1.-150.

\begin{tabular}{|c|c|c|c|c|c|c|}
\hline \multirow{4}{*}{ 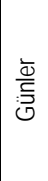 } & \multicolumn{6}{|c|}{ Mikroorganizma } \\
\hline & \multicolumn{2}{|c|}{ Koliform } & \multicolumn{2}{|c|}{ Enterokok } & \multicolumn{2}{|c|}{ Enterobactericeae } \\
\hline & $\begin{array}{c}\text { Diyet } \\
\text { Kısıtlaması }\end{array}$ & Kontrol & $\begin{array}{c}\text { Diyet } \\
\text { Kısıtlaması }\end{array}$ & Kontrol & $\begin{array}{c}\text { Diyet } \\
\text { Kısıtlaması }\end{array}$ & Kontrol \\
\hline & \multicolumn{2}{|c|}{ Ortalama \pm SEM } & \multicolumn{2}{|c|}{ Ortalama \pm SEM } & \multicolumn{2}{|c|}{ Ortalama \pm SEM } \\
\hline 1. & $3.98 \pm 0.41$ & $3.80 \pm 0.26$ & $5.14 \pm 0.27$ & $6.20 \pm 0.13$ & $3.54 \pm 0.34$ & $3.91 \pm 0.26$ \\
\hline 30. & $4.24 \pm 0.27$ & $3.37 \pm 0.29$ & $4.96 \pm 0.24$ & $6.24 \pm 0.19$ & $4.28 \pm 0.21$ & $3.42 \pm 0.55$ \\
\hline 60. & $4.53 \pm 0.35$ & $3.74 \pm 0.30$ & $5.88 \pm 0.37$ & $5.35 \pm 0.13$ & $4.47 \pm 0.24$ & $3.66 \pm 0.17$ \\
\hline 90. & $4.07 \pm 0.24$ & $4.27 \pm 0.28$ & $5.99 \pm 0.32$ & $6.06 \pm 0.18$ & $4.22 \pm 0.18$ & $4.48 \pm 0.38$ \\
\hline 120. & $4.24 \pm 0.11$ & $3.92 \pm 0.45$ & $5.49 \pm 0.36$ & $4.95 \pm 0.19$ & $4.45 \pm 0.14$ & $4.22 \pm 0.41$ \\
\hline 150. & $5.04 \pm 0.48$ & $3.07 \pm 0.22$ & $5.04 \pm 0.15$ & $4.31 \pm 0.36$ & $4.96 \pm 0.32$ & $3.11 \pm 0.16$ \\
\hline
\end{tabular}

\section{Tartışma ve Sonuç}

Diyet kısıtlamasının barsak mikroflorası üzerine etkisi üzerine gerçekleştirilen çalışma sayısı çok yetersizdir. Mevcut çalıșma diyet kısıtlamasının tek başına barsak mikroflorası üzerine etkisini ortaya koyan ilk araştırma özelliğini taşımaktadır. Bu konu ile ilgili yapılan akademik çalışmalar çeşitli veritabanlarında tarandığında sadece Elal Muş ve Ak Sonat (E Muş 2015) tarafından gerçekleştirilen diyet kısitlaması ile birlikte oral yolla $\beta$-glukan kullanımının ratların dıșkısında bulunan bazı bakterilerin gelişimine etkisinin araştırıldığı makale bulunmuştur.

Gerçekleştirilen çalışmaya ait mikrobiyolojik analiz sonuçları ile Elal Muş ve Ak Sonat'ın makale sonuçları karşılaştırıldığında; Mevcut çalışmada diyet kısıtlaması uygulanan ratların feçesindeki laktobasillerin sayısında anlamlı bir artış gözlenirken, diğer çalışmada (E Mus 2015) laktobasil sayısı 6 aylık diyet kısıtlaması sonrasında aynı düzeyde (başlangıç 9.02, bitiş $9.11 \log _{10} \mathrm{kob} / \mathrm{g}$ ) kalmış ve bundan dolayı istatistiksel olarak bir anlam tespit edilmemiştir. Koliform bakteri ve Enterobactericeae sayıları gerçekleştirilen çalışmada yaklaşık 1 log artış gösterirken, diğer araştırmada (E Muş 2015) bir değişiklik göstermemiştir (sırasıyla başlangıç ve bitiş düzeyleri 5.13-5.36, 5.27-5.44 $\log _{10} \mathrm{kob} / \mathrm{g}$ ). Enterokok sayıları ise yalnızca diyet kisitlamas1 uygulanan ratlar ile diyet kisitlamasiyla beraber $\beta$-glukan verilen ratların (E Muş 2015) feçesinde benzer sayılarda tespit edilmiştir.

Probiyotik bakteri olan laktobasiller antidiyareik, hipokolesterolemik, antienflamatuar, diyabeti geciktirici, kanseri önleyici etki gibi birçok sağlığa faydalı özelliğe sahiptir (Rajkumar 2015). Bu bağlamda rat örneğinde 150 günlük diyet kısitlaması barsak mikroflorasinda olması istenilen probiyotik laktobasiller üzerine olumlu etki meydana getirmiştir. Diğer bir taraftan yine barsak kaynaklı mikroorganizmalar olan koliform bakteri ve Enterobactericeae sayılarını arttırmıştır. Enterokok sayısını ise etkilememiştir. Gerçekleștirilen bu çalıșma sonucunda diyet kısitlamasının ratların barsak mikroflorasını değiştirme potansiyeline sahip olduğu belirlenmiștir.

\section{Kaynaklar}

1. Aydın 2007. Aydın C., Ince E., Koparan S., Cangul I.T., Naziroglu M., Ak F., 2007. protective effects of long term dietary restriction on swimming exercise-induced oxidative stres in the liver, heart and kidney of rat. Cell. Biochem. Funct., 25, 129-137.

2. Aydın 2009. Aydın C., Sonat F., Sahin S.K., Cangul I.T., Ozkaya G., 2009. Long term dietary restriction ameliorates swimming exerciseinduced oxidative stres in brain and lung of middle-aged rat. Indian J. Exp. Biol., 47, 24-31.

3. Coşkun 2006. Coşkun T., 2006. Pro-, pre- ve sinbiyotikler. Çocuk Sağlığı Hast. Derg., 49, 128148.

4. E Muş 2015. Elal Muss T., Ak Sonat F., 2015. The Effect of Orally Administrated $\beta$-glucan and Dietary Restriction on Faecal Microflora in Rats. Kafkas Univ. Vet. Fak .Derg., 21, 27-30.

5. Giller 2013. Giller K., Huebbe P., Hennig S., Dose J., Pallauf K., Doering F., Rimbach G., 2013. Beneficial effects of a6-month dietary restriction are time- dependently abolished within 2 weeks or 6months of refeeding genome-wide transcriptome analysis in mouseliver. Free Radic. Biol. Med., 61, 170-178.

6. Jackson 2002. Jackson M.S., Bird A.R., McOrist A.L., 2002. Comparison of two selective media for the detection and enumeration of Lactobacilli in human faeces. J. Microbiol. Methods, 51, 313321.

7. Koca 2015. Koca T.T., 2015. Barsak mikroflorasinın imflamatuvar hastalık patogenezindeki yeri. ARȘIV, 24, 78-91.

8. Rajab 2014. Rajab E., Alqanbar B., Naiser M.J., Abdulla H.A., Al-Momen M.M., Kamal A., 2014. Sex differences in learning and memory following short-term dietary restriction in the rat. Int. J. Devl. Neuroscience, 36, 74-80.

9. Rajkumar 2015. Rajkumar H., Kumar M., Das N., Kumar S.N., Challa H.R., Nagpal R., 2015. Effect of Probiotic Lactobacillus salivarius UBL 
S22 and Prebiotic Fructo-oligosaccharide on Serum Lipids, Inflammatory Markers, Insulin Sensitivity, and Gut Bacteria in Healthy Young Volunteers: A Randomized Controlled Single-Blind Pilot Study. J. Cardiovasc. Pharmacol. Ther., 20, 289-298.

10. Roberts 2003. Roberts D., Greenwood M., 2003. Practical Food Microbiology, 3th edition, Blackwell Publishing, Massachusetts, USA.

11. Robertson 2013. Robertson L.T., Mitchell J.R., 2013. Benefits of short-term dietary restriction in mammals. Exp. Gerontorol., 48, 1043-1048.

12. Shimokawa 2010. ShimokawaI., Trindade L., S., 2010. Dietary Restriction and Aging in Rodents: a Current View on its Molecular Mechanisms. Aging and Disease, 1, 89-104.
13. Speakman 2011. Speakman J.R., Mitchell S.E., 2011. Caloric restriction. Mol. Aspects Med., 32, 159-221.

14. Tüzün 2010. Tüzün C.G., Çiftçi İ., 2010. Kanatl1larda sağlıklı bağırsak mikroflorası gelişimi üzerine beslenmenin etkileri. Tavukçuluk Araştırma Dergisi, 9, 48-55.

15. Yanai 2004. Yanai S., Okaichi Y., Okaichi H., 2004. Long-term dietary restriction causes negative effects on cognitive functions in rats. Neurobiol. Aging, 25, 325-332. 
